\title{
Resilien Terhadap Pandemi Covid-19: Analisis terhadap Konten Youtube tentang Kesehatan, Ekonomi, dan Sosial
}

\author{
Anggriani Alamsyah ${ }^{1}$ \\ ${ }^{1}$ Universitas Islam Negeri Alauddin Makassar \\ e-mail: anggriani.alamsyah@uin-alauddin.ac.id \\ e-mil: ango iani.a
}

\begin{abstract}
Article Info
Article history:

Received

September $22^{\text {th }}, 2021$

Revised

December $4^{\text {th }}, 2021$

Accepted

December $4^{\text {th }}, 2021$

Published

December $5^{\text {th }}, 2021$

Abstract

This paper aims to describe various YouTube shows during the COVID-19 Pandemic regarding health, economic, and social aspects which are approached from a resilience perspective that focuses on adaptability and survivability. This paper is qualitative by using a variety of information on the YouTube platform as the object of writing which is analyzed descriptively-qualitatively which is in the period June 2020-April 2021. The results of the analysis of shows on health, economy, and social issues show that adaptability) is realized by accepting reality, defining reality, and flexibility. In addition, the ability to survive (survivability) is seen by achieving or maintaining a level of function and structure. This paper is expected to contribute both to the concept of resilience and the actualization of resilience, especially in the health, economic, and social fields of YouTube shows during the COVID-19 pandemic.
\end{abstract}

Keywords: adaptability; Covid-19; content; pandemic; resilience; survaviablity

\section{Abstrak}

Tulisan ini bertujuan menggambarkan beragam tayangan YouTube di masa Pandemi COVID-19 menyangkut kesehatan, ekonomi, dan sosial yang didekati dengan sudut pandang resilien yang memfokuskan diri pada adaptability dan survivability. Tulisan ini bersifat kualitatif dengan menggunakan beragam informasi di platform YouTube sebagai objek penulisan yang dianalisis secara deskriptifkualitatif yang berada dalam rentang waktu Juni 2020-April 2021. Hasil analisis dari tayangan-tayangan tentang kesehatan, ekonomi, dan sosial menunjukkan bahwa kemampuan adaptasi (adapablity) diwujudkan dengan penerimaan realita, mendefinisikan realita, dan fleksibilitas. Selain itu, kemampuan bertahan (survivablity) terlihat dengan mencapai atau mempertahankan level fungsi dan struktur. Tulisan ini diharapkan memberi kontribusi baik terhadap konsep resilien dan aktualisasi resilien, khususnya bidang kesehatan, ekonomi, dan sosial dari tayangan YouTube dimasa Pandemi COVID-19.

Kata Kunci: kemampuan beradaptasi; Covid-19; konten; pandemi; resilien; skemampuan bertahan hidup 


\section{PENDAHULUAN}

Wabah severe acute respiratory syndrome (SARS) yang disebabkan oleh SARS coronavirus (SARS-CoV) telah berlalu 17 tahun. Tepatnya November 2002 seorang pelatih binatang di Provinsi Guangdong, China yang dekat dengan makanan dari hewan buruan dan musang dianggap sebagai induk perantara. Tiga bulan kemudian virus ini telah tersebar melalui manusia secara cepat dan global, "super spreader" seorang professor bidang kesehatan yang mengunjungi keluarganya di Hongkong dari Foshan Provinsi Guangdong menyebarkan virus ini kepada dua anggota keluarganya, 4 petugas kesehatan (HCWs), dan 12 tetangga dekat. Negara lain yang terinfeksi virus ini adalah Vietnam, Singapura, dan Kanada. Akhirnya 8.422 orang terinfeksi di 32 negara dan 919 orang diantaranya meninggal dunia. SARS adalah pandemik virus corona yang paling pertama dengan kemampuan menyebar melalui droplet, tetapi bukanlah yang terakhir (Yang et al., 2020).

Vaksin, sepertinya pilihan terbaik untuk mencegah epidemic SARS-CoV dimasa datang. epidemics. Namun, kendala pertama yang menghalanginya adalah peneliti tidak memiliki pemahaman yang menyeluruh tentang mekanisme patogenis SARS-CoV. Kedua, model infeksi SARS$\mathrm{CoV}$ pada binatang tidak dapat disimulasikan pada manusia karena tiadanya keselarasan patogenis. Ketiga, untuk menguji kemanjuran, vaksin ini harus diujikan dibanyak orang di mana virus ini tersebar. Sekali epidemic SARS berakhir, percobaan terhadap manusia tidak lagi memungkinkan. Walaupun beberapa kandidat penangkal virus SARS-CoV telah diproduksi, sayangnya, tidak ada persetujuan FDA atasnya. Ketika pandemic Covid-19 melanda dunia, tidak ada rencana perawatan yang jelas, menyatu, dan efektif bagi Covid-19, kebanyakan hanyalah identifikasi awal, isolasi yang cepat, diagnosis lebih awal dan perawatan lebih awal (Yang et al., 2020). Namun, bagaimanapun vaksin sepertinya menjadi satu-satunya cara yang paling mudah untuk mencegah dan menghentikan penyebaran virus ini karena WHO berusaha mencapai kesuksesan besar dengan pembuatan COVAX (Covid-19 Akses Global Vaksin) yang bertujuan untuk mempercepat pengembangan dan produksi vaksin COVID -19 dan memastikan akses yang adil dan seimbang bagi semua negara di dunia. COVAX bertanggung jawab membeli vaksin dari pabrik-pabrik dan mengalokasikannya yang mendeklarasikan berpartisipasi dalam COVAX.

Rencana ini diimplementasikan melalui keterlibatan dua aliansi publik - swasta: Gavi (The
Vaccine Alliance) dan CEPI (Coalition for Epidemic Preparedness Innovations) in (Gavi 2021). Per Januari 2021, 98 negara-negara kaya dan 92 negara berpendapatan rendah berpartisipasi. Negaranegara yang lebih kaya membayar harga penuh yang dinegosiasikan Fasilitas COVAX dengan produsen vaksin. Negara yang berkembang juga diminta berkontribusi secara finansial, tetapi jika mereka tidak mampu, mereka akan diberikan gratis (Pradetto, 2021). Secara ideal, jika ini berjalan normal, diharapkan setiap negara mendapatkan vaksin secara adil. Kenyataannya gelombang ketiga pandemi Covid-19 membuat negara penghasil vaksin semisal India, harus mengurangi, bahkan menghentikan suplainya untuk COVAX karena India harus sangat membutuhkan vaksin tersebut untuk warganya sendiri. Adapula negara produsen vaksin yang menentukan sendiri kemana vaksin mereka akan disumbangkan, entah karena wilayah yang berdekatan, entah karena masing-masing terikat dengan kerjasama bilateral. WHO sebenarnya 'mengutuk keras' hal ini. Akan tetapi, sepertinya tidak membuat negara-negara produsen tersebut menghentikan bantuannya.

Fenomena pandemi di Indonesia nyaris tidak berbeda dengan belahan dunia lainnya. Virus ini sama sekali baru dan tidak satupun negara yang pernah mengalaminya, apalagi menanggulanginya. Setiap negara sama-sama bekerja keras untuk menanggulangi penyebaran virus tersebut. Masingmasing negara mencoba berbagai cara pencegahan dan penanggulangan yang mereka anggap bisa diterapkan di negaranya. China, Arab Saudi, Iran, dan Italia adalah negara-negara yang melakukan total lock down meskipun Italia agak terlambat melakukannya karena telah jatuh ratusan korban akibat pandemi ini.

Pemerintah kita terkesan maju mundur dalam menerapkan kebijakan lockdown. Berbagai pertimbangan menjadi alasannya yang utama adalah pertimbangan ekonomi. Masyarakat kita banyak yang menggantungkan hidupnya dari pendapatan harian, misalnya, para pedagang kaki lima dan pekerja bangunan. Tampak beberapa wilayah terkesan ambil langkah antisipatif dengan melakukan lockdown sebelum ada perintah dari pusat.

Pandemi ini seperti anak panah yang melesat langsung ke jantung perekonomian berbagai negara. Apalagi negara-negara yang sangat tergantung pada ekspor dan pariwisata seperti Indonesia. Banyak sektor jasa seperti perhotelan, transportasi dan kuliner, sport, pertokoan, juga otomotif, juga hiburan. Sektor-sektor yang banyak menampung pekerja ini 'dipaksa' gulung tikar, atau berinovasi jika tidak 
Anggriani Alamsyah, Resilien Terhadap Pandemi Covid-19: Analisis terhadap Konten Youtube tentang ...

ingin bisnisnya berakhir. Berbagai cara ditempuh sektor-sektor ini minimal untuk bertahan hidup. Perhotelan menawarkan jasa staycation dengan harga bersahabat, 'work from hotel,' 'food delivery from hotel', bisnis kuliner juga menawarkan layanan antar dan frozen food. Bisnis fashion menawarkan layanan antar sewa pakaian, bisnis hiburan menawarkan layanan streaming pertunjukan (konser) berbayar.

Bertahan hidup, itu salah satu dari sekian ungkapan penting di masa pandemic ini, kita dituntut untuk dapat 'berdamai' dengan keadaan yang tidak bisa kita ubah disekitar kita. Kita harus dapat menerima dan mebiasakan diri dengan beragam akibat dari pandemi ini. Bekerja dan belajar dari rumah, seminar dari rumah, membatasi berkumpul dengan orang banyak, ke mana-mana harus memakai masker, mencuci tangan lebih sering dari biasanya, hanyalah sebagian dari kenormalan yang baru yang, suka atau tidak suka, mau atau tidak mau, harus kita terima dan jalani. Resilien itu kata yang tepat untuk menggambarkan keadaan dimana kita berupaya untuk beradaptasi dengan perubahan yang terjadi disekitar kita dan nyaris tidak mungkin untuk kita ubah. Paul Robinson dalam film dokumenternya menggambarkan bahwa resilien dapat diartikan sebagai kemampuan untuk beradaptasi dan berubah, lebih dari kemampuan untuk memantul ke atas, resilien lebih kepada kemampuan untuk mengubah cara kita merespon keadaan tertentu dan mengalami pertumbuhan di tengah keadaan yang tidak pasti (Resilience-Documentary series-Episode 1-The Power to Overcome, YouTube diakses 28 Mei 2021).

Beberapa penelitian terdahulu menyangkut resilien diantaranya: "Resilience Thinking: Integrating Resilience, Adaptability and Transformability". Pemikiran resilien berfokus pada dinamika dan perkembangan sistem ekologi sosial yang kompleks (SES). Tiga aspek utamanya adalah: resilien, adaptability dan transformability. Aspek-aspek ini saling terhubung melintasi skala yang berganda. Resilien dalam konteks ini adalah kapasitas adalah kapasitas SES untuk berubah terus-menerus dan beradaptasi namun tetap diambang kritis. Adaptability adalah bagian dari resilience yang mewakili kapasitas untuk menyesuaikan respons terhadap penggerak perubahan eksternal dan proses-proses internal dan karenanya memungkinkan perkembangan sejalan dengan tujuannya (domain stabilitas). Transformability adalah kapasitas untuk melabrak batasan menuju lintasan perkembangan yang baru. Perubahan transformational pada skala lebih kecil memungkinkan resilien pada skala besar (Folke et al.,
2010).

Penelitian lainnya berjudul "On the Notion of Regional Economic Resilience: Conceptualisation and Explanation". Selama beberapa tahun belakangan ini, kata baru memasuki perbincangan akademik, politik, dan publik: perhatian pada resilien, istilah yang yang ditujukan untuk menggambarkan bagaimana entitas atau sistem merespon goncangan atau gangguan. Lebih jauh, resilien dengan cepat muncul sebagai ide 'yang telah tiba waktunya' dalam debat-debat kebijakan: sebuah penekanan baru dari 'konstruksi' atau 'membangun' resilien ekonomi regional dan urban adalah memperoleh mata uang. Namun, ketergesaan menggunakan ide resilien ekonomi regional dan okal dalam lingkar kebijakan agak menjauh dari pemahaman kita akan konsep tersebut. Masih ada ambiguitas tentang apa, tepatnya, makna resilien ekonomi global, tentang bagaimana dia dikonseptualisasi dan diukur, apa penentunya, dan bagaimana keterhubungannya dengan pola-pola pertumbuhan regional jangka panjang. Tulisan ini ditujukan untuk memperjelas hal ini dan pertanyaan yang berhubungan dengan makna dan penjelasan resilien ekonomi regional dan karenanya untuk menguraikan arah agenda riset (Martin \& Sunley, 2015).

Tema resilien juga diurai dalam tulisan yang berjudul "The Construct of Resilience: A Critical Evaluation and Guidelines for Future Work". Tulisan ini menyajikan penilaian kritis terhadap resilien, sebuah sebuah konstruksi konotasi pemeliharaan adaptasi positif oleh individu, meski mengalami baragam cobaan. Sebagaimana riset empiris tentang resilien telah berkembang beberapa tahun ini, kritik bermunculan diarea ini. Kritik-kritikini, berfokus pada ambiguitas dalam definisi dan terminology utama; heterogenitas resiko yang dialami dan kompetensi yang diperoleh oleh individu yang dianggap resilien; instabilitas fenomena resilien; dan perhatian terhadap kegunaan resilien sebagai konstruksi teoritis. Penulis mengindentifikasi kritik dan mengajukan solusi yang dianggap sah dan mengklarifikasi kesalahpahaman di sekeliling yang dianggap kurang valid (Luthar et al., 2000).

Dari beberapa penelitian terdahulu yang diuraikan di atas menggambarkan beberapa hal menyangkut resilien. Ada yang melihatnya dari level sistem ekologi, juga resilien yang dibahas dari pendekatan perkembangan ekonomi baik lokal, regional maupun urban, tidak ketinggalan pula bahasan yang mencoba 'meredakan' kritik terhadap konsep resilien. Tulisan ini memfokuskan diri kepada 
IKOMIK: Jurnal Ilmu Komunikasi dan Informasi 1(2) 2021 85-93

uraian tentang informasi-informasi yang terkait pandemi Covid-19 (kesehatan, ekonomi, dan sosial) yang ada di Youtube yang dikaji dengan pendekatan resilien.

Dalam buku "Reaching Resilience (Handbook Resilience 2.0 for aid practitioners and policymakers)" (Www.reachingresilien.org, n.d.), resilien adalah kapasitas sistem komunitas, atau masyarakat untuk mencapai atau memelihara level fungsi dan struktur yang dapat diterima. Hal ini ditentukan oleh derajat dimana sistem sosial mampu mengorganisir dirinya untuk meningkatkan kapasitas untuk belajar dari bencana masa lalu untuk proteksi masa depan yang lebih baik dan untuk memperbaiki pengukuran pengurangan resiko (UNISDR, 2004: 6 volume II). Levine et al, berfokus pada 'sistem sosial' dan nampak bebas nilai karena sistem yang 'dinilai', bukan keadaan kelompok sosial tertentu. 'Resilien' kemudian mendorong analisis bebas nilai dengan berfokus pada hasil dan karakteristik resilien daripada mengenali perbedaan kekuatan yang merupakan akar dari kerentanan (Www.reachingresilien.org, n.d.). Sementara itu, Tuppett M. Yates menguraikan konsep resilien yang tepat adalah proses perkembangan atau kapasitas dinamis daripada hasil atau kebiasaan yang statis. Sementara Masten berpendapat bahwa resilien dapat diaplikasikan dalam lingkup cakupan yang luas, mulai dari anak, keluarga, hingga institusi dan masyarakat, resilien meliputi kapasitas dari sistem dinamis untuk sukses beradaptasi terhadap kekacauan yang mengancam fungsi, kehidupan dan perkembangan dari sebuah sistem. Dalam konteks ilmu terapan, resilien juga adalah konotasi dari adaptasi positif atau perkembangan tertentu meskipun terpapar ancaman dan masalah yang nyata. Identifikasi proses resilien menuntut definisi operasional yang tepat atas masalah dan adaptasi positif atau kompetensi (Vereen et al., 2018).

"Six Foundations for Six Foundations for Building Community Building Community Resilience" menjabarkan bahwa resilien adalah kemampuan sebuah sistem (seperti komunitas) untuk menyerap gangguan dan tetap berada pada fungsi dan struktur dasarnya. Membangun resilien berarti secara sengaja memandu proses adaptasi system untuk memelihara beberapa kulaitas dan membiarkan lainnya menghilang, semua sambil mempertahankan esensi atau "identitas" - dari sistem. Dalam komunitas manusia, identitas secara esensial ditentukan oleh apa yang orang nilai tentang dimana mereka tinggal. Namun, apa yang dinilai komunitas secara kolektif terbuka bagi interpretasi dan subyek dari perdebatan.
Hal ini menunjukkan bahwa manusia dan cara mereka mencapai konsensus yang berat adalah pusat dari bangunan resilien komunitas.

Tulisan tersebut mengemukakan ini enam pondasi bangunan resilien komunitas: 1) People. Kekuatan untuk membayangkan masa depan komunitas dan membangun resiliennya bersama anggota-anggota komunitas; 2) Systems thinking. Pemikiran system esensial untuk memahami krisis yang kompleks yang sedang berlangsung dan maknanya bagi komunitas kompleks yang serupa; 3) Adaptability. Komunitas yang beradaptasi terhadap perubahan adalah resilient (tangguh). Tetapi karena komunitas dan tantangan yang kita hadapi bersift dinamis, adaptasi adalah proses yang terus menerus; 4) Transformability. Beberapa tantangan sangatlah besar sehingga tidak hanya dapat dihadapi dengan beradaptasi; perubahan yang fundamental, transformative mungkin dibutuhkan; 5) Sustainability. Resilien komunias tidak berkelanjutan jika hanya membanu kita, dan hanya sekarang; resilien perlu berguna bagi komunitas yang lain, generasi selanjutnya, dan ekosistem di mana kita semua bergantung; 6) Courage. Sebagai individu dan sebagai komunitas, kita perlu keberanian untuk menghadapi isu-isu yang menantang dan bertanggung jawab bagi masa depan bersama (Lerch, 2015). Dari berbagai sudut pandang yang membahas resilien, maka dalam dalam tulisan ini resilien diterjemahkan sebagai kemampuan seseorang atau suatu sistem untuk dapat beradaptasi (adaptability) yang diterjemahkan sebagai kemampuan untuk mengubah cara kita merespons keadaan tertentu dan bertahan (survivability) yang mengandung makna kemampuan untuk tetap bertumbuh di tengah keadaan yang tidak pasti demi terpeliharanya fungsi dan struktur yang ada.

Resilien tidak hanya berada dalam lingkup self (diri) tetapi bisa juga melingkupi ruang bisnis dan lingkungan manusia. Beragam informasi tentang kemampuan untuk beradaptasi, bertahan dan berubah dapat ditemukan diberbagai media, salah satunya adalah YouTube. YouTube adalah salah satu platform media sosial dengan diversifikasi informasi yang sangat luas. Media sosial merupakan pemain signifikan dalam lingkungan baru ini. Media sosial adalah prediktor terkuat diantara semua saluran informasi, diikuti oleh tontonan TV kabel; pertunjukan komedi tengah malam dan radio adalah prediktor yang negatif. Penulis menyimpulkan bahwa saluran komunikasi individual tidak memotivasi partisipan sebanyak perhatian pada kaukus. Temuan menunjukkan bahwa kampanye harus menjauhkan 
Anggriani Alamsyah, Resilien Terhadap Pandemi Covid-19: Analisis terhadap Konten Youtube tentang ...

pemilih dari situs pasif dan mengembangkan konten media sosial yang akan menghasilkan 'suka' dan 'berbagi' (Williams, 2017).

Media sosial sekarang ini menjadi alat yang manjur untuk mengekspresikan opini, pandangan, dan ide, dan menjadi alat yang berpengaruh untuk pembentukan opini. Menurut Palmer and KoeningLewis (2009), media sosial adalah platform aplikasi online yang memfasilitasi interaksi, kolaborasi, dan berbagi konten. Teknologi web 2.0 menyediakan pengalaman web dari buzz (dengungan) yang mewakili keterikatan mereka dalam berbagi informasi. Bahan tidak hanya disediakan pemilik situs, tetapi juga penghasil konten yang aktif berbagi pengalaman personalnya, menyajikan feedback, dan mengekspresikan sentimennya baik dalam bentuk positif, negatif, maupun netral (Luo \& Zhang, 2013 dalam Safiullah et al., 2017).

Jaringan sosial virtual sangat penting dan berguna bagi bisnis (Stefko, Dorcak, \& Pollak, 2011). Menurut Eyrich, Padman, dan Sweetser (2008), industri-industri menggunakan media sosial untuk mempertahankan hubungan publiknya (Curtis et al., 2010). Lembaga pendidikan tinggi menggunakan media sosial untuk mengajar, belajar dan berbagi (Moran, Seaman, \& Tinti-Kane, 2011). Media sosial adalahelemenhybriddaricampuranpromosi(Mangold \& Faulds, 2009). Taylor and Kent (2010), menyatakan bahwa taktik media sosial harus mempertimbangkan strategi public relation. Penggunaan media sosial tidak terbatas pada perusahaan untuk memelihara relasi publiknya, tetapi juga komponen media sosial muncul sebagai alat periklanan penting dalam pemilihan dan menjadi platform potensial untuk mengekspresikan opini secara lebih luas, misalnya pemilihan presiden Amerika Serikat (Smith, 2009), pemilihan umum Selandia Baru 2011 (Cameron, Barrett, \& Stewardson, 2015), 2010 Pemilihan Korea (Kim, 2011), dan pemilihan Swedia tahun 2010 (Larsson \& Moe, 2012 dalam Safiullah et al., 2017)

Saat masa pandemi ini, salah satu media yang mengalami perkembangan yang signifikan dan 'menuai' keuntungan adalah YouTube yang dipandang sebagai media sosial yang paling mempengaruhi pemikiran dan perilaku penontonnya yang jumlahnya 1,9 Milyar per Juli 2019. Beragam informasi dapat kita temukan di media ini, mulai dari anak-anak yang mereview mainan sampai yang lebih sulit hingga contoh soal-soal CAT. Ada yang mungkin yang kita anggap bermanfaat, tetapi ada yang kita anggap sebagai informasi remeh temeh. Beberapa public figure yang biasanya tampil di TV, akhirnya punya kanal
YouTube-nya masing-masing, dengan target audience yang beragam. Helmy Yahya, Gita Wirjawan, Denny Sumargo, Deddy Corbuzier, hanya sebagian kecil public figure yang akhirnya punya kanal media sosial ini. Konten yang mereka sajikan pun beragam yang pada intinya memberikan informasi yang mereka anggap bermanfaat buat target audiensnya.

Jika penelitian terdahulu menyorot resilien pada level system ekologi, adapula yang mengkhususkan diri pada perkembangan ekonomi, namun kali ini penulis ingin menyajikan resilien dari sudut pandang yang berbeda, yakni kemapuanadaptasi(adaptability)dankemampuan bertahan (survivability). Penulis tertarik melihat beragam informasi yang yang menyangkut kesehatan, sosial, dan ekonomi yang terbentang di YouTube yang menyangkut Covid-19. Di awal pandemi ada yang memberikan gambaran cara mencegah dan mengatasi dampak buruk virus yang mungkin saja sudah masuk ke dalam tubuh tanpa kita sadari. Mulai info tentang minyak kayu putih, menghirup uap panas, lantunan ayat-ayat suci yang dipercaya bisa mencegah efek negatif virus, injeksi/konsumsi vitamin, makan yang cukup dan lainnya. Juga tayangan tentang realitas sosial yang terjadi akibat pandemi ini. Bantuan kepada masyarakat terdampak, baik berupa bantuan langsung tunai ataupun paket sembako, paket nasi bungkus yang banyak dilakukan oleh masyarakat. bantuan kepada UMKM, juga pemotongan ataupun penggratisan pembayaran listrik dengan daya tertentu, penundaan pembayaran cicilan untuk yang berpendapatan tertentu, insentif perpajakan dan stimulus kredit usaha kecil. Tidak ketinggalan bagaimana cara berbisnis, atau mempertahankan bisnis di tengah pandemic ini. Beragam tips membuat makanan/ kue yang mudah dan digemari, minuman kekinian, ataupun frozen food, juga tips dan trik menjalankan bisnis fashion di tengah pandemic ini. Tulisan ini bertujuan menggambarkan beragam tayangan YouTube di masa Pandemi Covid-19 menyangkut kesehatan, ekonomi, dan sosial yang didekati dengan sudut pandang resilien yang memfokuskan diri pada adaptability dan survivability.

\section{METODE}

Tulisan ini bersifat kualitatif dengan menggunakan beragam informasi di platform YouTube 
sebagai objek penulisan. Tayangan yang dikumpulkan berada dalam rentang waktu Juni 2020-April 2021. Pendekatan resilien yang memfokuskan diri pada adaptability dan survivability yang digunakan untuk menganalisis secara deskriptif-kualitatif berbagai tayangan kesehatan, ekonomi, dan sosial dalam rentang waktu tersebut.

\section{HASIL DAN PEMBAHASAN}

Meskipun resilien memiliki banyak pengertian dari berbagai sudut pandang dan level pembahasan, tulisan ini melihat resilien dari dua sudut pandang yakni: Adaptability (accept reality, redefine reality, fleksibility) dan Survivability (reach or maintain an acceptable level of functioning and structure).

\section{Adaptability (accept reality, redefine reality, fleksibility)}

Pada Mei 2020 dapat kita temukan konten yang berjudul "Gaya Meledak-ledak, dr. Tirta Gencar Mengedukasi Tentang Bahaya Virus Corona”, senada dengan tayangan ini, pada bulan yang sama konten bertajuk "Sosok dr. Tirta Yang Lantang Berjuang Memberantas Covid-19" atau "Kami Butuh Makan, Bukan Masker" (November 2020), juga tayangan yang agak 'mengguncang'yang ditayangkan di podcast Deddy Corbuzier pada tanggal 19 Mei 2020 yang mengangkat tema "Corona Jelas Konspirasi!! Saya Jelaskan - Bossman Mardigu Sontoloyo WP”. Ya!!! Virus ini ada, menyebar dan bisa menyerang siapa saja, tidak mengenal status sosial, pekerjaan, agama, ras, dan kebangsaan, dia makhluk yang bisa berada di mana saja karena tidak kasat mata dan menyerang tidak kenal waktu dan keadaan. 'Wajah'-nya bisa berbentuk apa saja, kehilangan penciuman, gangguan perut akut, kesulitan bernapas, sakit kepala seperti nyaris pecah, atau tanpa 'wajah' sama sekali, tetapi 'berdiam' di tubuh manusia. Hal inilah sebagian realitas yang harus kita terima dan mencoba melakukan definisi ulang atasnya, kita nyaris tidak dapat menghilangkannya, kita hanya dapat menghindarinya dengan cara-cara yang telah dikampanyekan oleh petugas kesehatan.

Pengangguran di mana-mana, bisnis hancur lebur, angka kematian akibat Covid-19 bertambah, pengemis jalanan yang semakin banyak, rumah sakit yang tidak bisa menampung pasien Covid-19, belum lagi gangguan kejiwaan yang harus dialami oleh orang-orang yang masih sulit menerima kenyataan yang ada. Dunia memang tidak selamanya berjalan sesuai keinginan dan rencana kita. Akan tetapi, jika kita hanya bisa menganggap diri sebagai 'korban' dan 'menyalahkan' orang lain, nyaris tidak akan ada jalan keluar yang kita dapatkan. Dalam buku David Richo "5 Things We Can't Change" menguraikan bahwa ada lima hal yang berada diluar kendali kita dan tidak dapat kita ubah: 1) every thing change \& ends; 2) things do not always go according to plan; 3) life is not always fair; 4) pain is part of life; 5) people are not always loving and loyal. Alih-alih menyalahkan orang lain, ada baiknya kita mulai berpikir, apa yang akan kita lakukan setelah ini. Karena pada dasarnya kita nyaris tidak bisa mengendalikan apa yang telah, sedang, dan akan terjadi di sekitar kita. Kita minimal hanya bisa mengendalikan tiga hal, pikiran kita, emosi kita dan prilaku kita. Kejadian yang terjadi disekitar kita menuntut kemampuan untuk mengubah cara kita merespon keadaan tertentu. Hal yang membedakan kita dengan orang lain adalah cara kita bereaksi terhadap apa yang terjadi dan pada hal-hal yang berada diluar kendali kita.

Adaptasi dimulai dari diri kita, jika kita telah dapat menerima realitas yang ada menyangkut pandemik dan segala akibatnya, sedikit banyak itu akan mengubah keadaan di luar tubuh kita. Tubuh yang 'menerima' keadaan ini sebagai sesuatu yang tidak dapat diubah, akan membuat imunitas kita membaik yang pada akhirnya membuat tubuh kita lebih berenergi dan memikirkan langkah-langkah yang harus diambil mengahadapi semua ini. Pada Juni 2020 medcon.id menayangkan di Youtube konten yang berjudul "Covid-19 Tidak Bisa Hilang Kita Perlu Adaptasi Baru”, juga konten dengan tajuk "Tidak Dengan Obat, Dokter Mengatakan Hanya Ini Yang Bisa Membunuh Virus Covid-19 di Dalam Tubuh" (November 2020). Virus, pandemi, masker, lockdown adalah istilah yang sangat populer dalam lebih satu tahun belakangan ini. Jika kita hendak keluar dari rumah, rasanya ada yang kurang jika kita tidak memakai masker dan membawa handsanitizer. Begitu pula halnya jika hendak memasuki bank, perkantoran, ataupun pertokoan seorang petugas keamanan akan memeriksa suhu tubuh kita adalah hal yang lumrah setahun belakangan ini.

Reinhart Niebuhr mengemukakan konsep yang dinamakannya 'Serenity Prayer', God, grant me the serenity to eccept the things I cannot change, the courage to change the things a can, and the wisdom to know the difference. Pandemi 'memaksa' kita untuk belajar bahwa ada banyak hal yang diluar kendali kita dan tidak dapat kita ubah. Seseorang yang selama in harus bekerja dari pagi ketika anak-anaknya belum bangun, kini punya kebiasaan baru bahkan melakukan Shalat Berjamaah dengan anak-anak mereka, menggantikan guru yang hanya dapat mengajar dengan cara virtual, 
Anggriani Alamsyah, Resilien Terhadap Pandemi Covid-19: Analisis terhadap Konten Youtube tentang ...

makan siang bersama mereka, menghabiskan waktu bersantai hingga tiba saatnya untuk beristirahat di malam hari. Fenomena yang mungkin tidak pernah kita bayangkan sebelumnya, fleksibilitas kita menetukan berhasil atau tidaknya kita melampaui semua ini. Sebab tidak jarang rasa bosan melanda, sepanjang waktu kita hanya berada di rumah dengan orang yang sama, yang bisa saja menimbulkan masalah baru.

Beberapa konten di YouTube yang bisa menggugah 'urat' fleksibilitas kita diantaranya yang menawarkan ide untuk berbisnis dari rumah, bahkan hanya dengan bermodal foto karena kita hanya berperan sebagai re-seller. Konten-konten tersebut antara lain: "Cara Mencari Distributor Frozen Food (Desember 2020), Ide Usaha Ikan Siap Goring Vacuum Frozen (Desember 2020), Brulee Bomb -Ide Jualan Frozen Food (Desember 2020), Dan Tips Memulai Bisnis Frozen Food (Januari 2021) atau Konten Dengan Judul "Belajar Bisnis Bersama dr. Tirta” (Oktober 2020). Sekali lagi fleksibilitas kita yang merupakan hasil dari penerimaan kita atas apa yang terjadi memungkinkan kita untuk memanfaatkan sisi positif dari kejadian ini, tidak jarang kita dengar, dengan lebih banyaknya waktu di rumah, maka seseorang dapat mengembangkan bakat bercocok tanam, menjahit, menyulam, berbisnis dari rumah atau kebiasaan lain yang sulit dilakukan jika keadaan normal.

Bumi dan penghuninya telah melihat, menerima dan beradaptasi dengan pandemic ini, bumi nampak lebih tenang, langit lebih biru, ketika lockdown dijalankan. Manusia-manusia menjalani kenormalan baru dan menjadikannya kebiasaan, fleksibilitas kita benar-benar diuji di masa ini, pandemik memang bukan hal yang bisa kita cegah kedatangannya, tetapio bersamanya kita tetap harus menjalani hidup dan kehidupan senormal mungkin.

\section{Survivability (reach or maintain an acceptable level of functioning and structure)}

Dunia dan segala permasalahannya tidak bisa hanya diselesaikan semata oleh satu atau dua negara, karena apa yang terjadi di satu belahan dunia sedikit banyak akan berpengaruh kepada negara lainnya. Semisal masalah pemanasan global, tidak hanya diselesaikan oleh negara-negara yang bertanggung jawab sehingga hal itu terjadi, tetapi juga negaranegara yang bisa mencegah hal ini semakin meluas. Dalam dunia global dengan ketergantungan ekonomi dan pasar, lalu lintas lintas batas dan migrasi, dan isu-isu kesehatan - seperti pemanasan global - tidak dapat lagi diselesaikan dengan local, nasional atau regional daripada pemanasan global. Ini dinyatakan secara dalam setiap tulisan strategi secara virtual pada subyek tersebut. Kebenaran hubungan antara factor kesehatan, ekonomi, sosial, dan politik. Kemiskinan dan kesenjangan pendidikan menyebabkan gangguan kesehatan dan sebaliknya. Pemerintahan yang buruk meningkatkan deficit dalam semua factor. Tanpa keterhubungan sektor-sektor relevan dan memperkuat koordinasi internasional dan lembaga internasional, dengan Organisasi Kesehatan Dunia (WHO) di awal, masalah tidak dapat diselesaikan (Pradetto, 2021). Demikian pula halnya dengan penanganan pandemic Covid-19, tidak bisa hanya dihadapi oleh negara secara individual, tetapi kejadian luar biasa ini menuntut kerja sama semua negara untuk menanganinya bersama-sama.

Sampai tulisan ini dibuat (27 Mei 2021), korban Covid-19 di Indonesia telah mencapai 1.791.221 orang (Kompas.com). Juru bicara Satgas penanganan Covid-19 Prof. Wiku Adisasmito memaparkan bahwa dampak tersebut sudah terlihat dalam data perkembangan penanganan mingguan per 23 Mei 2021. Terjadi penurunan tingkat kesembuhan dan peningkatan kasus positif dan kematian, umumnya pada wilayah tujuan arus mudik dan arus balik. Sebanyak lima provinsi berkontribusi terhadap peningkatan ini diantaranya Jawa Barat 2.221 orang, DKI Jakarta 1.240 orang, Sumatra Barat 959 orang, Jawa Tengah 948 orang, dan Aceh 561 orang (CNBC Indonesia.com diakses tanggal 27 Mei 2021).

Setelah lebih dari setahun diluluhlantakkan oleh pandemi, dunia berangsung memulihkan diri baik secara ekonomi, sosial, maupun kesehatan. Mall, rumah makan, pariwisata perlahan mulai diijinkan untuk beroperasi namun harus memperhatikan prosedur kesehatan yang ada, Indonesia dan dunia sedang mengalami 'kenormalan baru'. Memakai masker dan membawa hand sanitizer menjadi pemandangan yang biasa. Beberapa bulan belakangan ini, vaksin mulai diperkenalkan dan diberikan gratis kepada masyarakat, meskipun beragam kontroversi masih menyelemuti keberadaannya. Vaksin yang digunakan di Indonesia berasal dari Biofarma, Sinovac, Pfizer, Sinopharm, Moderna, dan AstraZeneca.

Beberapa tayangan di YouTube yang membahas vaksi Covid-19 diantaranya "Mengapa Indonesia Pilih Vaksin Dari China? Erick Tohir Menjawab" (28 Agustus 2021), "Mengenal Jenis Vaksin" (16 Desember 2020), pada tanggal 23 Januari 2021 konten dengan judul "Menjawab Keraguan Vaksin Covid-19". Vaksinasi adalah salah satu langkah krusial yang bisa 
dianggap penentu kesuksesan untuk mengakhiri pandemi Covid-19 dan sebagai cara efektif untuk dapat bertahan agar fungsi dan struktur tetap dapat berjalan normal (Lerch, 2015). Untuk itu, pemerintah mengupayakan stok vaksin untuk bisa mencapai target 181,5 juta orang agar herd immunity (kekebalan kelompok) terbentuk. Per 25 Mei 2021, Indonesia sudah menerima 83.910.500 dosis vaksin Covid-19, yakni sebesar 73.500 .000 vaksin bulk Sinovac yang akan diolah Bio Farma menjadi sekitar 59 juta dosis vaksin jadi, serta 10.410 .500 dosis vaksin jadi dari Sinovac, AstraZeneca, dan Sinopharm (covid19.go.id diakses 27 Mei 2021).

Kemampuan untuk bertahan dimasa pandemic ini tentu tidak hanya dalam hal kesehatan, tetapi juga menyangkut bidang ekonomi, beberapa hal yang dilakukan oleh para pebisnis untuk dapat tetap bertahan hidup adalah membuat strategi dagang yang berbeda ataupun melakukan diversifikasi usaha. Strategi diversifikasi adalah strategi pertumbuhan perusahaan dimana perusahaan memperluas aktivitasnya dan memasuki aktivitas bisnis yang baru, untuk melebarkan area investasi untuk profit dan pertumbuhan, menghasilkan pertumbuhan yang konsisten dan stabil

(Tipuric \& Darabos, 2012). Salah satu contoh nyata diversifikasi usaha adalah yang dilakukan oleh desainer Ivan Gunawan, dengan membuka kafe, membuat bakso aci, dan membuat peyek dengan beragam rasa, diversifikasi usaha ini tentu berdampak bagi terbukanya lapangan kerja bagi orang-orang yang terdampak pandemi ini. Upaya untuk bertahan sekaligus memberi kesempatan bagi kelangsungan hidup orang lain.

Meskipun menyimpang jauh dari core bisnis utama, hal itu bukanlah penghalang untuk melakukan strategi diversifikasi. Sebagaimana yang diungkapkan oleh (Tipuric \& Darabos, 2012) bahwa memungkinkan bagi sebuah peusahaan untuk membuka bisnis lain yang tidak berhubungan dengan bisnis utamanya. Alasannya bisa beragam memberikan dukungan kepada divisi yang sedang mengalami kesulitan dalam pertumbuhannya, menggunakan profit dari divisi yang berbeda untuk menutupi kerugian divisi yang lain; mendorong pertumbuhan, mengambil keuntungan atas kesempatan untuk berkembang, distribusi resiko dengan pasar yang berbeda dan terpisah; meningkatkan keuntungan dan fleksibilitas; meraih akses yang lebih baik untuk pasar modal dan stabilitas yang lebih baik serta memperoleh pertumbuhan; meningkatkan harga saham; atau mewujudkan keuntungan dari sinergi.
Cara lain yang ditempuh untuk tetap bertahan adalah dengan menetapkan sistem shift harian bagi para pekerja, ataupun memotong gaji menjadi setengah, semua dilakukan agar tidak terjadi pemecatan dan usaha bisa tetap berjalan. Ada pula upaya dengan melakukan beragam strategi penjualan misalnya yang dilakukan oleh Pizza Hut Makassar, dengan harga 100 ribu, kita sudah memperoleh empat buah pizza. Penjualan ini dilakukan ke lokasi-lokasi yang harsu ditempuh selama kurang lebih tiga jam untuk bisa sampai kesana, juga di beberapa tempat di dalam Kota Makassar. Pizza Hut juga melakukan audisi Selebizza (YouTube, April 2021) atau menjual pizza dalam bentuk persegi panjang ukuran semester (YouTube April 2021).

Saatini dunia sedang dihadapkan oleh pandemik gelombang ketiga karena korban kembali bertambah, bahkan yang sudah divaksin pun, juga tidak terbebas dari virus ini. Meskipun pandemi ini sudah menelan jutaan korban, manusia telah belajar dari bencana masa lalu untuk proteksi masa depan yang lebih baik (UNISDR dalam www.reachingresilien.org), perekonomian dan keadaan sosial juga berangsur membaik melalui diversifikasi usaha dan perubahan strategi pemasaran. Fenomena resilien ternyata tidak hanya bisa diteliti di dunia nyata, tetapi juga bisa diamati dari tayangan-tayangan YouTube. Tulisan ini 'menyorot' sisi adaptif dan bertahan dari konsep resilien untuk membedah tayangan kesehatan, ekonomi, dan sosial dari platform ini.

\section{SIMPULAN}

Resilien dan pandemi sepertinya dua hal yang bisa disejajarkan saat ini. Pandemi membuat guncangan yang hebat bagi hampir seluruh penduduk bumi. Wabah ini menyebar tanpa bisa dibendung, menghancurkan rencana banyak orang, tetapi tampaknya justru mewujukan impian baru bagi sebagian lainnya. Seberapapun buruknya dampak negatif dari pendemi ini, manusia harus dapat belajar untuk beradaptasi (adapability) dan bertahan hidup (survivability) atasnya. Tulisan ini telah memberikan sebagian gambaran bagaimana masyarakat Indonesia beradaptasi dengan wabah ini dan mencoba untuk bertahan hidup, baik dari segi kesehatan maupun pada pondasi sosial ekonominya. Adaptability dan survivability adalah kunci utamanya.

\section{DAFTAR PUSTAKA}

Folke, C., Carpenter, S. R., Walker, B., Scheffer, M., \& Chapin, T. (2010). Resilien Thinking: Integrating Resilien, Adaptability and. 15(4). 
Lerch, D. (2015). Six Foundations for Building Community Resilien.

Luthar, S. S., Cicchetti, D., \& Becker, B. (2000). The construct of resilien: A critical evaluation and guidelines for future work. In Child Development. https://doi. org/10.1111/1467-8624.00164

Martin, R., \& Sunley, P. (2015). On the notion of regional economic resilien: Conceptualization and explanation. Journal of Economic Geography. https:// doi.org/10.1093/jeg/lbu015

Pradetto, A. (2021). Covid-19 , International Power Structures, and Global Health Policy. 1-16.

Safiullah, M., Pathak, P., Singh, S., \& Anshul, A. (2017). Social media as an upcoming tool for political marketing effectiveness. Asia Pacific Management Review, 22(1), 10-15. https://doi.org/10.1016/j. apmrv.2016.10.007

Tipuric, D. D., \& Darabos, M. (2012). The frequency of implementing diversification strategy in Croatia. The Business Review.
Vereen, L. G., Yates, C., Hudock, D., Hill, N. R., Jemmett, M. K., O'Donnell, J., \& Knudson, S. (2018). The Phenomena of Collaborative Practice: the Impact of Interprofessional Education. International Journal for the Advancement of Counselling, 40(4), 427-442. https://doi.org/10.1007/s10447-018-9335-1

Williams, C. B. (2017). Introduction: Social Media, Political Marketing and the 2016 U . S . Election Introduction: Social Media, Political Marketing and the 2016 U . S . Election. Journal of Political Marketing, 16(3-4), 207-211. https://doi.org/10.108 $0 / 15377857.2017 .1345828$

www.reachingresilien.org. (n.d.). Handbook Resilien 2.0 for aid practitioners and policymakers.

Yang, Y., Peng, F., Wang, R., Guan, K., Jiang, T., Xu, G., Sun, J., \& Chang, C. (2020). The deadly coronaviruses: The 2003 SARS pandemic and the 2020 novel coronavirus epidemic in China. Journal of Autoimmunity, 109(February), 102434. https://doi. org/10.1016/j.jaut.2020.102434 